\title{
ANOTHER LOOK AT COYOTES
}

\section{HANS DE VOGEL,}

Box 219,

Neilburg, Saskatchewan

SOM 2CO

The day is just beginning when I get to the pasture. A mist hangs over the sloughs, and everything is damp and wet. A House Wren starts her quick little song; she must have a nest in an old woodpecker's hole. On the water, I can hear the muttering and splashing of mudhens, still invisible. Redwings are calling, and across the water in a patch of bullrushes, Yellow-heads croak. A pair of Crows fly over silent for once!

This lease land is supposed to be parkland, but it is turning more and more into an aspen forest with open spaces. The big low meadows have been under water for the last 20 years, and are not better adapted to raising ducks, muskrat and beaver, than to grazing cows.

In the pasture, I stop to listen, but all I hear is coyotes yodelling far away in the direction of the den. I picture the mother sitting on the hilltop with her offspring, greeting the newborn day.

Finally I find the whole herd of cows bedded down around a salt block, still new and square. A rough count indicates that they are all there. A little apart, a cow is licking a very young, beautiful heifer calf. She must have brought it back into the herd from its secret birthplace just this morning. I carefully note the new mother's eartag number on the flap of my cigarette papers, then roll a cigarette and perch comfortably on the block of salt, to injoy the first rays of the sun.

Some of the cows are now getting up. They arch their backs, curl their ails and stretch one leg for good neasure, then without fail relieve hemselves. Calves run to their nothers for breakfast.

Suddenly the grazing horse throws up its head. Right in the middle of the cows is a beautiful big coyote with a mallard drake clamped in his jaws. The cows neither look nor miss a beat in their cud-chewing. This must be a daily occurrence to them. Any moment I expect the coyote to get my scent, whirl around and streak away, but the odour of the cows and of the freshlykilled prey seem to keep him from smelling me. He comes nearer and nearer, head held high to keep from stepping on the dangling duck. Passing within 50 feet of me, he disappears over the hill in the direction of the den, carrying food to the young.

On the way home I start wondering about coyotes. This coyote carrying food was a male, so it is clear that both parents look after the pups. Ordinary dogs, after mating, take no responsibility for the pups. Could it be that the male coyote, by contrast, once accepted by the female, stays with her and helps feed the young during the denning period?

Years ago I rode along a bush trail with our farm dog. He was about 100 yards ahead of the horse when suddenly he stopped and wagged his tail slowly as all dogs do when they are not sure of the reception they will get from strangers. Two coyotes appeared on the trail, one much bigger than the other. Both acted as if they wanted to play, and the big one rolled over a couple of times. Our Mutt rushed up in joyful bounds, and the coyotes ran ahead of him looking sideways as only coyotes do. The trio disappeared around a bend in the trail. A mile further on, the dog suddenly appeared again behind the horse, looking none too happy. I am sure this was a case of a pair of coyotes coaxing the dog away from their young.

There is much to learn yet about our wild yodellers. It is too bad most peole only see coyotes through the scope of a rifle, as dead carcasses near poison baits, or desperately plunging through deep snow ahead of a roaring skidoo. 